\title{
Potential Analysis of Coffee Agritourism in Penggung Village, Nawangan District, Pacitan Regency
}

\author{
Jenvia Rista Pratiwi ${ }^{1}$, Rita Parmawati ${ }^{2}$, Luchman Hakim ${ }^{3}$ \\ \{jenviapratiwi24@gmail.com ${ }^{1}$ \} \\ Universitas Brawijaya, Indonesia ${ }^{1,2,3}$
}

\begin{abstract}
Based on the Pacitan Regional Spatial Plan in 2005-2025, Bandar and Nawangan District were designed to become the Agropolitan area. The agriculture and plantation sectors dominate both areas. In Penggung Village, located in Nawangan, almost of the household have a Coffee Plantation. It encourages the emergence of the local coffee product named TopCo. Therefore, this research aimed to analyze the environmental characteristics of Penggung Village in Nawangan District of Pacitan Regency in order to develop a coffee agritourism. The method in this research was interview using a questionnaire, which was carried out in qualitative descriptive analysis and observation. The results showed the natural resources in the Penggung village are highly potential compared to other indicators. That is because coffee trees are commonly found in the yard of nearly every village community. But, in order to maintain the sustainability of Coffee plantation, there must be more socialization or training to the community related to the management of good coffee agritourism so that it can support the development of coffee agritourism in Penggung Village, Nawangan District, Pacitan Regency.
\end{abstract}

Keywords: Agritourism, Coffee, Topco.

\section{Introduction}

Coffee is the commodities that become an essential role in the national economy. Coffee takes effect as a producer of foreign exchange, income of farmers, producers of industrial raw materials, and can create jobs and regional development [1]. Furthermore, coffee a source of income for no less than one and a half million people of coffee farmers in Indonesia [2].

Indonesia is ranked 4th in the world as the most significant coffee production. The level of coffee consumption in Indonesia increased in 2016 by $1.1 \mathrm{~kg}$ per capita. This indicates that people's interest in coffee drinks is increasing. The increasing population in Indonesia has an impact on increasing coffee consumption by the community.

In the journey of coffee evolution in the world, coffee drinks have entered the third wave phase. Third wave phase of coffee is a term that describes a way to consume, enjoy and appreciate high-quality coffee. It considers coffee an artisanal food like wine, whose consumption experience can be enhanced with higher education, connoisseurship and sensory exploration beyond just a cup of coffee. Third wave coffee describes an approach that seeks highlight the unique characteristics that result from the diversity of coffee bean cultivar, growing and cultivar methods, processing, roasting methods and the variable in beverage preparation [2]. 
One of the coffee-producing areas in Pacitan Regency is Penggung Village, Nawangan District. The type of coffee planted is liberica coffee which is rarely found elsewhere. That is because liberica coffee is one of the leading commodities in Penggung Village, Nawangan District, Pacitan Regency.

Based on the Pacitan Regional Spatial Plan in 2005-2025 Bandar and Nawangan District was designed to become Agropolitan region. The agriculture and plantation sectors dominated both areas. Penggung Village has the potential in the coffee sector and also has the potential to be developed as a coffee garden agritourism [3].

The development of coffee garden agritourism was carried out to support the Pacitan Regional Spatial Plan in 2005-2025. Therefore, it is important to conduct this research to analyze the environmental characteristics in the Pacitan Regency agropolitan area for the development of coffee agritourism.

\section{Method}

The study was conducted in Penggung Village, Nawangan District, Pacitan Regency. Data was collected from August 2019 to October 2019. The total population in Penggung Village was 6704 people, so the Slovin formula are available. Using significance level of $10 \%$ to take samples and the result was 98 people respondents.

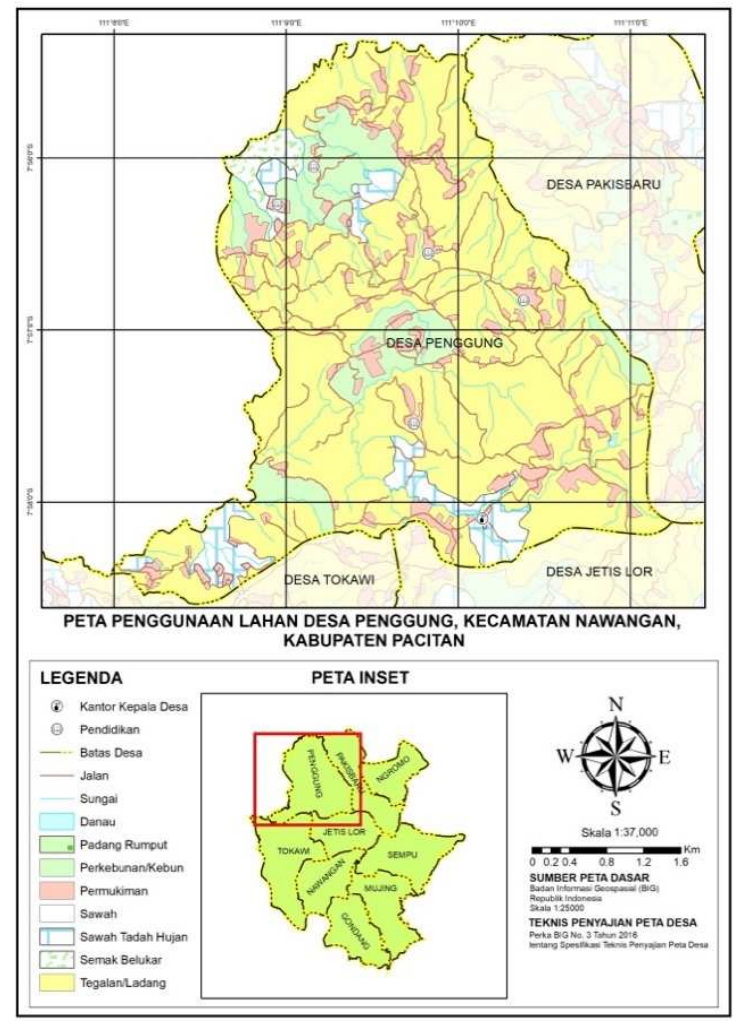

Fig. 1. Map of research location. 
The data used are secondary data and primary data. Primary data were obtained from respondents through field interviews. Primary data used among other respondent's identity, cultivation techniques, post-harvest management, marketing, yield management. Secondary data is used to support primary data in research from related agencies such as village monograph data in Penggung Village, Nawangan District, Pacitan Regency.

The variables observed were natural resources, human resources, infrastructure and technology. Then the data were analyzed quantitative descriptive.

\section{Result}

Penggung Village has a topographic area with an altitude of 700-1,150 meters above sea level. Penggung Village is crossed by a provincial road that connects East Java and Central Java. The area of land used for coffee plants is $85 \mathrm{Ha}$. The soil type in Penggung Village for paddy soil is 187.3 ha and 1,346 Ha is dry land. With the most job the people of Penggung Village are farmers (Profil Desa Penggung, 2018). Based on the land use map (Figure 1) the majority of land use in Penggung Village is fields.

Table 1. Frequency human resources variable

\begin{tabular}{llc}
\hline & \multicolumn{1}{c}{ Indicator } & Respondents \\
\hline \multirow{4}{*}{ Last education } & Junior High School & 9 \\
\cline { 2 - 3 } & Senior High School & 86 \\
\cline { 2 - 3 } & Bachelor & 3 \\
\hline \multirow{4}{*}{ Skill/training } & Agriculture & 71 \\
\cline { 2 - 3 } & Coffee production training and brewing & 14 \\
\cline { 2 - 3 } & Training other coffee & 4 \\
\cline { 2 - 3 } & No training & 9 \\
\hline
\end{tabular}

Based on the frequency of human resources (Table 1), mostly the education level in Penggung Village is Senior High School (86 respondents), Junior high school (9 respondents), and Bachelor ( 3 respondents). Meanwhile, for skill or training in the community, most of the citizens have agriculture skill (71 respondents), already participate in coffee production and brewing training (14 respondents), Training other coffee (4 respondents), and citizen that have not participated in training (9 respondent).

Fourteen respondents had received training in coffee production and coffee brewing, followed by "Karang taruna" and owners of Topco coffee producers. Meanwhile, nine respondents did not receive any training. That is because respondents were not directly involved in agriculture or coffee making in Penggung Village, known as Topco coffee.

Table 2. Frequency natural resources variable

\begin{tabular}{|c|c|c|}
\hline & Indicator & Respondents \\
\hline \multirow{2}{*}{ Natural resources potential } & Agriculture & 93 \\
\hline & High Land & 5 \\
\hline \multirow{3}{*}{ Kind of potential } & Coffee & 83 \\
\hline & Orange & 4 \\
\hline & Fruits & 11 \\
\hline
\end{tabular}




\begin{tabular}{lll}
\hline \multirow{3}{*}{ Location of coffee } & Centralized plantations & 38 \\
\cline { 2 - 3 } & Separate plantations & 41 \\
\cline { 2 - 3 } & Forest & 19 \\
\hline \multirow{3}{*}{ Accessibility } & Asphalt & 43 \\
\cline { 2 - 3 } & Asphalt and a little rocky & 51 \\
\cline { 2 - 3 } & Rocky and a little asphalt & 4 \\
\hline
\end{tabular}

Based on the frequency of natural resource variables (Table 2), 93 respondents answered the potential of natural resources that can be developed is agriculture. Meanwhile, 5 respondents answered that the potential of natural resources is high land (Mountain). The location of the coffee plantation is in the yard of the house with separate plantations type, in line with the status of the area, which is rural. The most potential production in Penggung Village is coffee plants (83 respondents), oranges (4 respondents), and other fruits (11 respondents). For the accessibility components of Penggung Village, mostly road is asphalt (43 respondents), asphalt and some rocky (51 respondents), and rocky and some asphalt (4 respondents).

Table 3. Frequency facilities and infrastructure variable

\begin{tabular}{|c|c|c|}
\hline & dicator & Respondents \\
\hline \multirow{3}{*}{ Fertilizer } & Agriculture shop & 2 \\
\hline & Farmers (POKTAN) & 77 \\
\hline & Other & 19 \\
\hline \multirow{2}{*}{ Coffee production } & In each farmer's house & 10 \\
\hline & A few house & 88 \\
\hline \multirow{2}{*}{ Home stay } & A few & 10 \\
\hline & No & 88 \\
\hline \multirow{2}{*}{ Market } & Active & 93 \\
\hline & Passive & 5 \\
\hline \multirow{3}{*}{ Accessibility } & Asphalt & 43 \\
\hline & Asphalt and a little rocky & 51 \\
\hline & Rocky and a little asphalt & 4 \\
\hline \multirow{2}{*}{ Public transportation } & Rarely & 85 \\
\hline & No & 13 \\
\hline \multirow{2}{*}{ Medical facility } & Primary health care center & 87 \\
\hline & Auxiliary health care center & 11 \\
\hline
\end{tabular}

Based on the frequency of facilities and infrastructure variable (Table 3), the majority of citizens obtained fertilizer through farmer groups (POKTAN), while those who do not join farmer groups (POKTAN) can buy fertilizer from agriculture shop or use organic fertilizer from the livestock disposal. In contrast, there is only one coffee processing facility that produces ground coffee products in Penggung Village. There are no lodging places in Penggung Village. There is a market to sell coffee beans that have been dried by farmers with asphalt accessibility, whereas public transportation is rare because it only exists for particular days. Health facilities in Penggung Village are the primary health care center and auxiliary health care center. However, most people come to the primary health care center. 
Table 4. Frequency technology variable

\begin{tabular}{|c|c|c|}
\hline \multicolumn{2}{|c|}{ Indicator } & Respondents \\
\hline \multirow{2}{*}{ Land rejuvenation } & Not yet & 79 \\
\hline & Do not know & 19 \\
\hline \multirow{3}{*}{ Planting process } & Superior quality seeds & 2 \\
\hline & From the previous tree & 81 \\
\hline & Do not know & 15 \\
\hline \multirow{2}{*}{ Post-harvest management } & Sold dry & 79 \\
\hline & Sold wet & 19 \\
\hline \multirow{3}{*}{ Marketing } & Market with middleman & 85 \\
\hline & Market without middleman & 7 \\
\hline & Local coffee producer & 6 \\
\hline
\end{tabular}

Based on the frequency of the technology variable (Table 4), most of farmers have not rejuvenated the land are 79 farmers, and 19 respondents did not know about it because they are not a farmer. The planting process carried out by most of farmers are seedlings from previous trees as much as 81 respondents. Meanwhile, 2 respondents were used superior quality seeds, and 15 respondents did know because their work was not a farmer. Postharvest management, as many as 79 farmers sell their corps in dry conditions and the rest as much as 19 farmers sell their corps with wet conditions. The majority of the marketing crop is sold to the local coffee producers are 5 farmers, and most of them sold to market with a middleman as much as 85 farmers.

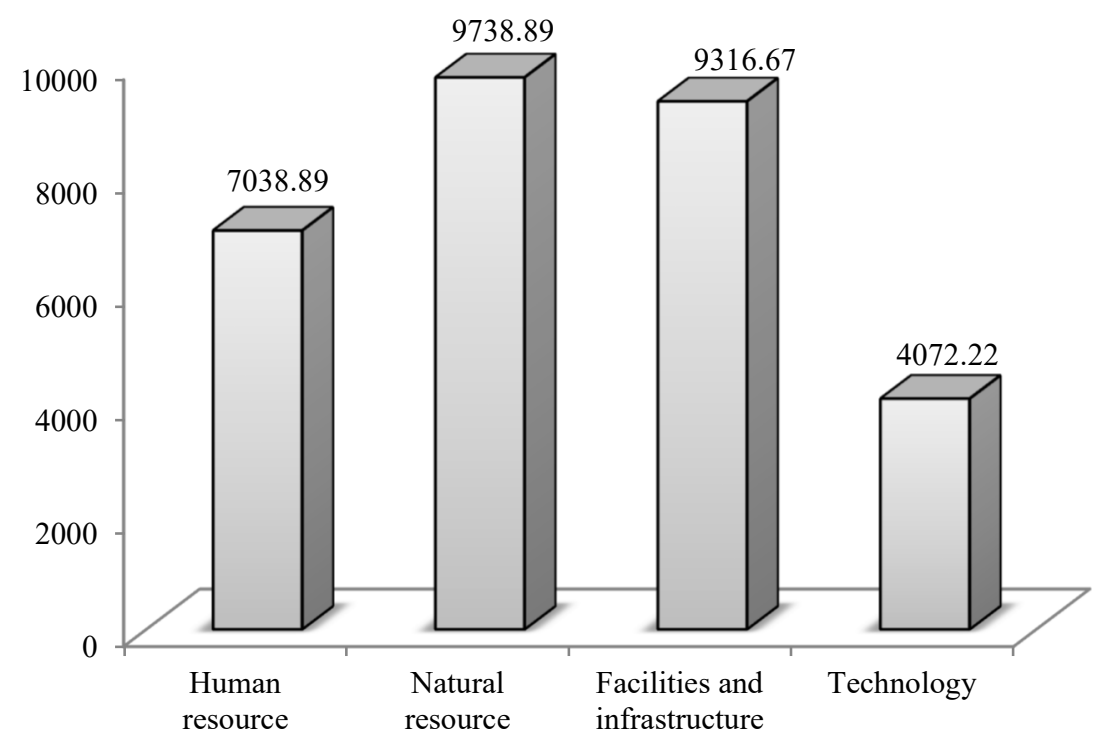

Fig. 2. Variable value.

Based on the graph above (Figure 2), it can conclude that the Natural resources variable has the highest value of 9738.89 , and followed by the physical variable of 9315.67. The third variable is human resources at 7038.89, and the lowest value is 4072.22. 
The natural resources variable has the highest value. It because the potential of natural resources that can utilize for the development of agropolitan areas is agriculture. It is following the agropolitan area itself, where agriculture is the primary commodity. Another potential is the highlands which can develop as nature tourism.

Facilities and infrastructure variables have a value of 95.07 because most facilities and infrastructure are available. So, the next step that must take is the development of related facilities and infrastructure in order to support other variables. The human resource variable has a high enough value. That is because there has been training related to the development of the Agritourism Area. The technology variable has the lowest number of values among the four other variables. That is because the planting technology used by farmers is less than optimal. Related training has already been carried out, but several factors still make farmers afraid to practice it. As when the tree rejuvenation process is carried out, the impact that will be felt by farmers is that no harvest can generate income to hamper the economy.

\section{Discussion}

Agritourism development needs to be supported by the development of all agricultural subsystems that are carried out in an integrated manner. All agritourism subsystems are bound in a unified area, so to develop agritourism, regional development is necessary. Agritourism development can be carried out based on the interaction of existing subsystems, superior products as a characteristic of agritourism reinforcement and around environmental [4][5][6].

The development of Penggung Village into coffee plantation agritourism can be carried out considering the potential of natural resources, which are the coffee farmers. The development of the concept of agritourism, which is almost the same, is found in Gombengsari Village, Bayuwangi Regency. The concept of coffee garden tourism development with rural areas so that abundant natural resources are agriculture, especially in coffee plants [7]. However, characteristics of Penggung Village is the location of the coffee garden located in the residents' yard so that tourists will immediately get information about how to cultivate coffee trees directly from farmers.

Development of the concept of community-based coffee agritourism will also require useful human resources. It can be seen from the factor level of education and skills possessed. The last education level of the respondents affected the way to receive information and new things that had not been obtained by farmers before. It is in line with research conducted by Pratiwi [8], which states that the level of education, age, and work experience influences attitudes and actions towards new information obtained by farmers. Old farmers tend to be less dynamic and less open to new things because they are based on previous experience [8].

The community has a vital role in reducing the occurrence of urban sprawl. It can be done by increasing the ability of the people involved [9]. The empowerment is done by considering the age factor, education level that is followed, and the experience of farming (coffee) from farmers. In general, factors that have an influence on-farm management patterns and on their acceptance of changes (innovation) that leads to a better direction, although to implement it (new technology/innovation) still requires the support of other factors such as capital, the availability of inputs and the existence of market guarantees for the products they produce [10]. 


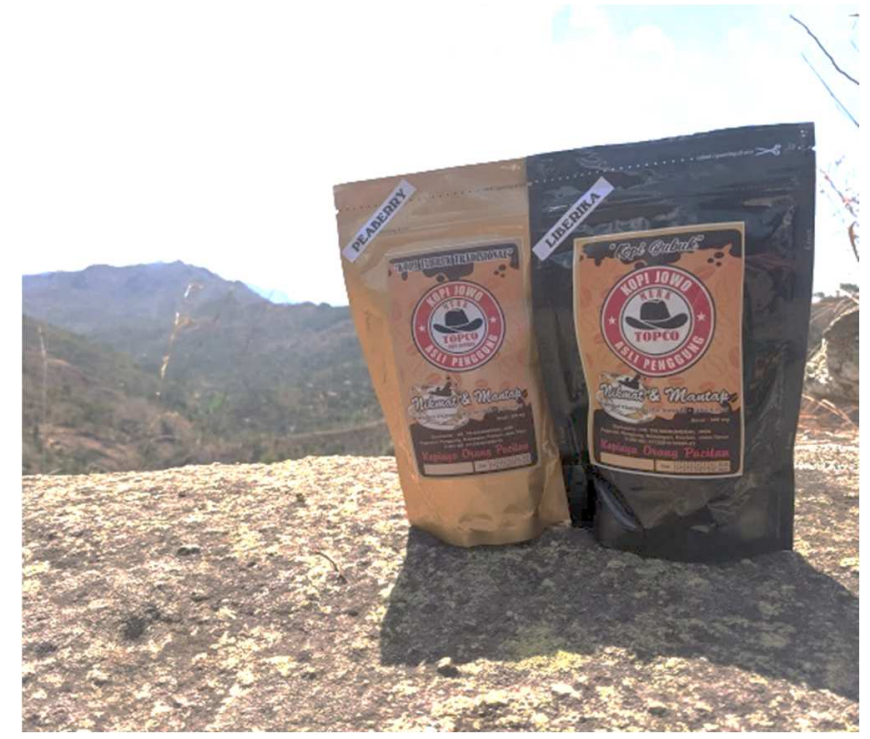

Fig. 3. Topco Coffee (local brand of Penggung Village).

Penggung Village has a local brand, Topco Coffee. Produced by one resident and involving "Karang taruna" in production coffee and marketing. However, the marketing techniques carried out are still manual. So, socialization or training regarding product marketing is needed for human enhancement resources in Penggung Village.

Facilities and infrastructure are also factors supporting tourist attractions, which in this case, are coffee plantations. Road conditions, easy access to attractions, lodging, health facilities, and supporting attractions must also be provided. In terms of road conditions, it is very supportive because a provincial road passes Penggung Village between East Java and Central Java. However, what still needs to be considered is the availability of lodging and supporting attractions.

The availability of the necessary infrastructure must be available and appropriate for use. Such as facilities and infrastructure such as rest areas, MCK, shopping, road systems, and telecommunications systems. Also, transportation, the education system, and health facilities are included in the infrastructure that must be present in a tourism system. The facilities needed to meet the demand of tourists to enjoy the tour. Things needed include restaurants, lodging, and travel agents [11][12]. 


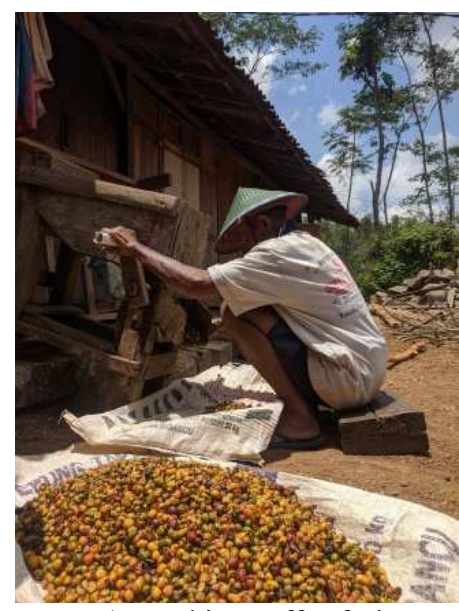

a) Breaking coffee fruits

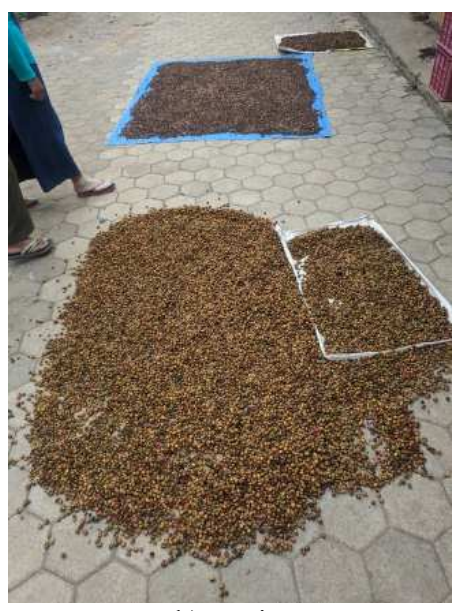

b) Drying

Fig. 4. Production of Topco Coffee.

Coffee tree cultivation carried out by farmers is also an essential variable in order to know the sustainability of the coffee plant. The planting process carried out by farmers generally uses coffee beans from the previous plant. However, some farmers do not do nurseries and only depend on coffee trees whose age is more than 20 years.

The seeds used by farmers are not classified as superior seeds, so the quality of coffee produced is also less than optimal. That is because there is no supply of superior quality coffee seeds. As for post-harvest management, farmers generally have to fertilize with the remaining livestock manure owned by each farmer.

Coffee (Coffea $s p$.) is a C3 plant, with the characteristic of low photosynthetic efficiency due to photorespiration. Low photosynthetic efficiency causes the growth rate of coffee plants to be not optimal. Therefore, in order for coffee plants to grow and produce optimally, these plants need to be given shade plants. The shade plants for coffee plants has a benefit such as reducing the intensity of sunlight, reducing the temperature difference between day and night, keeping the microclimate more stable, sources of organic matter, wind resistance and erosion, extending the life of the coffee production period (over 20 years), reduce excess production (overbearing), and to improve the quality of coffee [13].

The majority of shade plants used by coffee farmers in Penggung Village are lamtoro (Leucaena sp.) and sengon (Paraserianthes falcataria). Shade plants and coffee plants need pruning to regulate light intensity.

\section{Conclusion}

Based on the research results above, Penggung Village has the potential of a coffee plantation that can be developed with the concept of agritourism seen from natural resources in the agricultural sector, which is abundant with the highest potential types of coffee plants. Human resources with the latest educational background are not too low, and some farmers have received training. As for the youth group, they have received training on how to produce coffee and make coffee. 
The development of facilities and infrastructure in the form of lodging and supporting attractions needs to be done to complement the needs of tourists. The cultivation of coffee trees by farmers is not optimal. So, it needs to be done in-depth training for coffee farmers. Also, the determination of coffee plantation commodity zoning along with production facilities in the form of working capital, provision of high-quality seeds, and adequate technical guidance for coffee farmers and Penggung Village community is needed.

\section{References}

[1] R. Hariance, R. Febriamansyah, and F. Tanjung, "Agribisnis perkebunan rakyat kopi Robusta di Kabupaten Solok,” J. AGRISEP Kaji. Masal. Sos. Ekon. Pertan. dan Agribisnis, vol. 14, no. 1, pp. 11-25, 2015.

[2] P. S. M. Boaventura, C. C. Abdalla, C. L. Araujo, and J. S. Arakelian, "Value co-creation in the specialty coffee value chain: the third-wave coffee movement," Rev. Adm. Empres., vol. 58, no. 3, pp. 254-266, 2018.

[3] BPS Kabupaten Pacitan, Kabupaten Pacitan Dalam Angka 2018. Pacitan: Citra Mandiri Printing, 2018.

[4] F. Aref and S. S. Gill, "Rural tourism development through rural cooperatives," Nat. Sci., vol. 7, no. 10, pp. 68-73, 2009.

[5] W. Kuswidiati, "A Case Study of Participatory Development in the One Village One Product Movement: Green Tourism in Ajimu Town, Oita, Japan and Agro Tourism in Pasuruan, East Java, Indonesia,” J. OVOP Policy, vol. 1, no. 11, pp. 67-75, 2008.

[6] L. Hakim, "Planning for nature-based tourism in East Java: recent status of biodiversity, conservation, and its implication for sustainable tourism," ASEAN J. Hosp. Tour., vol. 7, no. 2, pp. 155-167, 2008.

[7] Y. Kristiana, S. Lien, and W. Liauw, "Pengembangan Paket Wisata di Desa Gombengsari Kabupaten Banyuwangi,” J. Sains Terap. Pariwisata, vol. 4, no. 1, pp. 12-24, 2019.

[8] R. R. Pratiwi, "Hambatan dan strategi pengembangan usahatani kopi dalam upaya peningkatan produksi di kecamatan candiroto kabupaten temanggung." Universitas Negeri Semarang, 2016.

[9] G. Laverack and S. Thangphet, "Building community capacity for locally managed ecotourism in Northern Thailand," Community Dev. J., vol. 44, no. 2, pp. 172-185, 2009.

[10] N. I. Minsyah, "Keragaan Agro-Ekonomi Kopi Liberika Tungkal Komposit pada Lahan Gambut Kabupaten Tanjung Jabung Barat," 2016.

[11] L. Trimo, G. W. Mukti, and H. Fauziana, "Kajian Strategi Pengembangan Agrowisata Kopi Luwak (Studi Kasus Kopi Luwak Manglayang, Kampung Pondok Buahbatu-Cikawari, Desa Mekarmanik, Kecamatan Cimenyan, Kabupaten Bandung)," Agricore J. Agribisnis dan Sos. Ekon. Pertan. Univ. Padjadjaran, vol. 3, no. 2, 2018.

[12] O. A. Yoeti, "Perencanaan \& pengembangan pariwisata," Jakarta PT Pradnya Paramita, 2008.

[13] Y. Ferry, H. Supriadi, and M. S. D. Ibrahim, "Teknologi Budi Daya Tanaman Kopi: Aplikasi Pada Perkebunan Rakyat.” IAARD, 2015. 